[13], which uses dialysed samples; a commercially available microcolumn procedure (Quik-Sep ${ }^{\circledR}$, Isolab Inc, Akron, Ohio), which uses undialysed samples [11]; and the same commerical procedure modified by using dialysed haemolysate. When the 6-hour changes were assessed, there was a significant positive correlation ( $r=$ 0.68 ) between the change in blood glucose and that of $\mathrm{HbAI}$ with the commerical microcolumn technique, using undialysed samples; however, no such relationship was present when either the macrocolumn or the microcolumn method with dialysed haemolysates was used. Indeed, the rapid fluctuations in glycohaemoglobin related to acute changes in glucose made the commerical unmodified method useless for the evaluation of long-term control in unstable juvenile diabetics without dialysis.

These observations and those of others [14] of the degree and rapidity of $\mathrm{HbAI}$ changes suggest that the glycosylation process may, to some degree, be rapid and easily reversible. However, these fluctuations may well be a reflection of recent fluxes in glucose, and dialysed haemolysates may better reflect long-term glucose control and conform more closely to the originally held concept of $\mathrm{HbA}_{\mathrm{Ic}}$ as a slowly changing index of long-term blood glucose control.

\section{References}

1. Bolli G, Cartechini MG, Compagnucci P, Santeusanio F, Massi-Benedetti M, Calabrese G, Puxeddu A, Brunetti P (1980) Modification of glycosylated haemoglobin concentration during artificial endocrine pancreas treatment of diabetes. Evidence for a short-term effect on $\mathrm{HbA}_{\mathrm{I}(\mathrm{a}+\mathrm{b}+\mathrm{c})}$ levels. Diabetologia 18: $125-130$

2. Dunn PJ, Cole RA, Soeldner JS, Gleason RE, Kwa E, Firoozabadi H, Younger D, Graham CA (1979) Temporal relationship of glycosylated haemoglobin concentrations to glucose control in diabetics. Diabetologia 17: 213-220

3. Karamanos B, Christacopoulos P, Zachariou N, Korkolis S (1977) Rapid changes of the haemoglobin $A_{\mathrm{Ic}}\left(\mathrm{HbA}_{\mathrm{Ic}}\right)$ fraction following alterations of diabetic control. Diabetologia 13: 406

4. Svendsen PA, Christiansen JS, Welinder B, Nerup J (1979) Fast glycosylation of haemoglobin. Lancet I: 603

5. Stevens VJ, Vlassara H, Abati A, Cerami A (1977) Nonenzymatic glycosylation of hemoglobin. J Biol Chem 252: 2998-3002
6. Bunn HF, Haney DN, Kamin S, Gabbay KH, Gallop PM (1976) The biosynthesis of human hemoglobin $A_{\text {Ic. }}$ Slow glycosylation of hemoglobin in vivo. J Clin Invest 57: 1652-1659

7. Peterson CM, Jones RL (1977) Minor hemoglobins, diabetic "control", and diseases of postsynthetic protein modification. Ann Intern Med 87: 489-491

8. Ditzel J, Kjargaard JJ (1978) Haemoglobin $A_{\text {Ic }}$ concentrations after initial insulin treatment for newly discovered diabetes. $\mathrm{Br}$ Med J I: 741-742

9. Cole RA, Soeldner JS, Dunn PJ, Bunn HF (1978) A rapid method for the determination of glycosylated hemoglobins using high pressure liquid chromatography. Metabolism 27: 289-301

10. Kynoch PAM, Lehmann H (1977) Rapid estimation $(2-1 / 2$ hours) of glycosylated haemoglobin for routine purposes. Lancet II: 16

11. Abraham EC, Huff TA, Cope ND, Wilson JB Jr, Bransome ED Jr, Huisman THJ (1978) Determination of the glycosylated hemoglobins $\left(\mathrm{HbA}_{\mathrm{I}}\right)$ with a new microcolumn procedure. Suitability of the technique for assessing the clinical management of diabetes mellitus. Diabetes 27: 931-937

12. Bunn HF, Haney DN, Gabbay KH, Gallop PM (1975) Further identification of the nature and linkage of the carbohydrate in hemoglobin $\mathrm{A}_{\mathrm{Ic}}$. Biochem Biophys Res Commun 67: 103-109

13. Schwartz HC, King KC, Schwartz AL, Edmunds D, Schwartz R (1976) Effects of pregnancy on hemoglobin $A_{I c}$ in normal, gestational diabetic, and diabetic women. Diabetes 25: $1118-1122$

14. Widness JA, Rogler-Brown TL, McCormick KL, Petzold KS, Susa JB, Schwartz HC, Schwartz R (1980) Rapid fluctuations in glycohemoglobin (hemoglobin $\mathrm{A}_{\mathrm{Ic}}$ ) related to acute changes in glucose. J Lab Clin Med 95: 386-394

J. Ditzel

Department of Medicine

Aalborg Regional Hospital

DK-Aalborg, Denmark

\section{P. H. Forsham}

M. Lorenzi

Metabolic Research Unit and

Department of Medicine

University of California

San Francisco, CA, USA

\title{
Fetal Hypoinsulinism as a Cause of Small Infants of Smoking Mothers?
}

Sir,

The decrease in the mean birth weight of the infants of smoking mothers, as compared with those of normal non-smokers [1], may result from the relative hypoxia caused by carbon monoxide [2]. Nicotine [3] and other chemicals in tobacco smoke also may affect the birth weight reduction in these infants. The Ontario Perinatal Mortality Study [4] concluded that the reduction of birth weight in the offspring of smoking mothers is not due to a decrease in maternal nutrition as reflected in weight gain during pregnancy. However more subtle metabolic disturbances induced by smoking 
may be a contributory factor in the reduced birthweight of the infants of smoking mothers.

In a large prospective study in Paris, previously published [5-7] on 6930 adult professional workers, it has been pointed out that plasma glucose (PG) and insulin (PI) levels both fasting and two hours after a $75 \mathrm{~g}$ oral glucose load, were significantly lower in smoker's compared to non-smokers (see Table 1). Weight was also negatively related to tobacco consumption.

On the other hand, amniotic fluid insulin and/or C-peptide concentrations which might be considered as a reflection of fetal pancreas beta cell function, have been shown to be correlated with birthweight in normal [8] as well as in diabetic pregnancies [9].

As insulin is a well known growth promoting substance of the foetus, we would like to suggest that relative chronic fetal hypoinsulinism, in response to a relative maternal chronic hypoglycaemia may be a contributory factor in the reduced birthweight of the infants of smoking mothers.

\section{References}

1. Schwartz D, Goujard J, Kaminski M, Rumeau-Rouquette C (1972) Smoking and pregnancy. Results of a prospective study of 6989 women. Rev Eur Etudes Clin Biol 17: 867-879

2. Longo LD (1977) The biological effect of carbon monoxide on the pregnant woman, fetus and newborn infant. Am J Obstet Gynecol 129: 69-103

3. Krishna K (1978) Tobacco chewing in pregnancy. Br J Obstet Gynaecol 85: 726-728

4. Meyer MB (1978) How does maternal smoking affect birth weight and maternal weight? Evidence from the Ontario Perinatal Mortality Study. Am J Obstet Gynecol 131: 888-893

5. Eschwege E, Ducimetiere P, Papoz L, Richard J-L, Claude JR, Rosselin GE (1980) Coronary heart disease risk factors and OGTT plasma glucose and insulin levels. The Paris Prospective
Study. Xth Karlsburg Symposium in Early Diabetes, ed. Bibergeil, Zühlke, Poser, Central Institute for Diabetes, Karlsburg, part 1, 181-188

6. Ducimetiere P, Eschwege E, Papoz L, Richard J-L, Claude JR, Rosselin GE (1980) Relationship of plasma levels to the incidence of myocardial infarction and coronary heart disease mortality in a middle-aged population. Diabetologia 19: 205-210

7. Rosselin GE, Claude JR, Eschwege E, Patois E, Warnet J-M, Richard J-L (1971) Diabetes survey plasma insulin during 0-2 $\mathrm{H}$ oral glucose tolerance test systematically carried out in a professional group. Diabetologia 7: 34-35

8. Spellacy WN, Buhl WC, Bradley B, Kolsinger KK (1973) Maternal, fetal and amniotic fluid levels of glucose, insulin and growth hormone. Obstet Gynecol 41: 323-331

9. Tchobroutsky G, Heard I, Tchobroutsky C, Eschwege E (1980) Amniotic fluid $\mathrm{C}$ peptide in normal and insulin-dependent diabetic pregnancies. Diabetologia 18: 289-292

\section{E. Eschwege}

Groupe d'Etudes sur l'Epidémiologie

de l'Athérosclérose (GREA)

F-Villejuif

L. Papoz

U 21 Inserm

F-Paris

G. Rosselin

U 55 Inserm

F-Paris

C. Tchobroutsky

Maternité de Port-Royal

Université Pierre et Marie Curie

F-Paris

France

Table 1. Variations of weight, plasma glucose and plasma insulin values according to smoking habits

\begin{tabular}{|c|c|c|c|c|c|}
\hline & \multirow[t]{2}{*}{$\begin{array}{l}\text { Smokers }^{a} \\
(n=4006)\end{array}$} & \multirow[t]{2}{*}{$\begin{array}{l}\text { Non smokers } \\
(\mathrm{n}=2924)\end{array}$} & \multirow{2}{*}{$\begin{array}{l}\text { Significance level } \\
\mathrm{p}\end{array}$} & \multicolumn{2}{|c|}{$\begin{array}{l}\text { Correlation coefficient } \\
\text { with tobacco consumption }\end{array}$} \\
\hline & & & & $\mathrm{r}$ & $\mathrm{p}$ \\
\hline Weight $(\mathrm{kg})$ & $77.8 \pm 10.3^{\mathrm{b}}$ & $79.8 \pm 11.0$ & $<10^{-9}$ & -0.10 & $<10^{-9}$ \\
\hline Fasting plasma glucose, $\mathrm{mg} / \mathrm{dl}$ & $101 \pm 12$ & $102 \pm 11$ & $<10^{-3}$ & -0.02 & \\
\hline $2 \mathrm{~h}$ plasma glucose, $\mathrm{mg} / \mathrm{dl}$ & $102 \pm 36$ & $106 \pm 35$ & $<10^{-3}$ & -0.03 & $<0.05$ \\
\hline Fasting plasma insulin, $\mu \mathrm{U} / \mathrm{ml}$ & $11.8 \pm 9.8$ & $12.9 \pm 9.8$ & $<10^{-5}$ & -0.06 & $<10^{-5}$ \\
\hline $2 \mathrm{~h}$ plasma insulin, $\mu \mathrm{U} / \mathrm{ml}$ & $42.1 \pm 38.4$ & $48.4 \pm 44.6$ & $<10^{-9}$ & -0.08 & $<10^{-9}$ \\
\hline
\end{tabular}

\footnotetext{
a subjects who smoke more than 1 cigarette/day in the last five years
}

${ }^{b}$ Mean \pm SD 